\title{
Postharvest Treatment of Guava (Psidium guajava L.) Fruits with Boric Acid and NAA for Quality Regulation during Ambient Storage
}

\author{
Jatinder Singh, Narendra Prasad and Shailesh Kumar Singh*
}

Dept. of Horticulture, School of Agriculture, Lovely Professional University, Phagwara, Punjab (114 441), India

\section{Corresponding Author}

Shailesh Kumar Singh

e-mail: Ipushailesh@gmail.com

\author{
Article History \\ Manuscript No. AR1633a \\ Received in $3^{\text {rd }}$ July, 2016 \\ Received in revised form 19 $19^{\text {th }}$ Dec, 2016 \\ Accepted in final form 27 $7^{\text {th }}$ March, 2017
}

\begin{abstract}
Guava fruit exhibits a climacteric pattern of respiration and ethylene production so is highly perishable in nature and suffers great extent of post-harvest loss. Storage of guava fruits by using chemicals like $\mathrm{GA}_{3}$, Salicylic acid, NAA, potassium permanganate and boric acid as postharvest treatment is commercially acceptable and economically feasible. The present investigation was carried out with objective to compare the efficacy of boric acid and NAA and their most effective concentration for shelf-life enhancement of guava fruits in winter season. The fruit of guava, cv. Allahabad Safeda were harvested, selected for uniformity of size, colour and diseased fruits were discarded. Prior to the application of post-harvest treatments, destalking of the fruits was done by retaining only $0.5 \mathrm{~cm}$ long pedicels in each fruit. The destalked guava fruits were sorted and pre cooled in running water for 12-15 minutes. Fruits were treated with Boric acid @ 100 ppm, 200 ppm and 300 ppm, NAA @ 200 ppm, 300 ppm and 400 ppm for 1-2 minutes. The physical parameters like fruit size, fruit weight, physiological weight loss, decay of fruits and specific gravity; chemical parameters like TSS, titratable acidity, ascorbic acid and sugar content; and palatability rating were observed and compared with untreated fruits. Both, boric acid and NAA, had significantly affected the shelf life of guava fruits stored under ambient condition. Boric Acid 200 ppm and 300 ppm were equally effective, similarly NAA 300 ppm and $400 \mathrm{ppm}$ were equally effective for quality retention in guava fruits.
\end{abstract}

Keywords: Ascorbic acid, boric acid, guava, NAA, storage life

\section{Introduction}

Guava (Psidium guajava L.) belongs to family Myrtaceae and bears delicious fruits in three different seasons' viz., summer, rainy and winter crops. It is now being cultivated in many tropical and subtropical regions of the world including India, Brazil, Mexico, Florida, Hawaii, California, Peru, Egypt, South Africa, Algeria, Columbia, West Indies, China and Malaysia. In India, guava the apple of tropics, is fourth mostly grown fruit following Mango, Banana and Citrus (Singh et al., 2016). The major components of guava fruits are Vitamin 'C' (250 mg 100 $\mathrm{g}^{-1}$ fresh fruits), carbohydrates (13\%) and minerals (Calcium-29 $\mathrm{mg}$, Phosphorus-10 mg and Iron-0.5 mg $100 \mathrm{mg}^{-1}$ fresh fruits). Guava fruit exhibits a climacteric pattern of respiration and ethylene production (Mahajan et al., 2011). Usually the fruits are harvested at different stages of maturity depending on the situation. After reaching the physiological maturity it ripens fast in 1 or 2 days resulting in early senescence of the fruit.

Guava is a highly perishable fruit and post-harvest loss in guava fruits is estimated to be at 3.4-15.1\% (Madan and Ullasa, 1993). Because of high moisture content and thin and soft skin, guava fruits are subjected to higher rate of transpiration, respiration, ripening and other biological activities, even after harvest, which deteriorate the quality of the fruits in a short period and finally make them unmarketable. Increase in PLW (physiological loss in weight), TSS and sensory rating while decrease in firmness, acidity and ascorbic acid have been reported by Deepthi et al. (2016) under ambient conditions. Furthermore, its susceptibility towards pest and microbial attack results in short postharvest life (El-Anany and Hassan, 2013). Thus, it is necessary to reduce rates of these physico-chemical changes in order to enhance the storage life of guava fruits. Shelflife of fresh fruits can be extended through low temperature storage, edible coating, treatments with chemicals (as pre-harvest and post-harvest treatment), packaging films and use of ethylene adsorbents. These techniques are commodity specific so should be applied as per the fruits and availability. Storage of guava fruits by using chemicals like $\mathrm{GA}_{3}$ (Pila et al., 2010), Salicylic acid (Bal and Celik, 2010), NAA (Deepthi and Sekhar, 2015), potassium permanganate (Bal and Celik, 2010) and boric acid (Kaur et al., 2016) as postharvest treatment is commercially acceptable and economically feasible. These chemicals control the transpiration, respiration, ripening of fruits by regulating the biochemical changes in fruits, this will delay in internal ethylene synthesis in fruits and extend the period 
of availability of fruits in market. This will further reduce the wastage of fruits and minimize postharvest loss.

The post-harvest treatment of guava fruits with suitable chemicals like boric acid and NAA has positive impact to enhance shelf-life without drastic loss in nutrients. Thus, present investigation was carried out with objective to compare the efficacy of boric acid and NAA and their most effective concentration for shelf-life enhancement of guava fruits in winter season.

\section{Materials and Methods}

The present investigation were carried out at Horticulture department, School of Agriculture, Lovely Professional University, Punjab, during December, 2014. The experiment was laid in Complete Randomized Design (CRD) with seven treatments and three replications. Uniform size harvested fruits of guava were dipped in different chemicals with different concentrations like Boric acid @ 100 ppm, Boric acid @ 200 ppm, Boric acid @ 300 ppm, NAA @ 200 ppm, NAA @ 300 ppm and NAA @ 400 ppm for 1-2 minutes. After dipping the fruits were exposed in air for few minutes for drying. The dried fruits were packed in $2-5 \mathrm{~kg}$, polythene bags and stored at room temperature $\left(25 \pm 1^{\circ} \mathrm{C}\right)$ and $75 \% \mathrm{RH}$. Observations were recorded at 3, 6, 9 and 12 days of storage and effectiveness were compared with control (untreated fruits stored under similar condition).

The impact of postharvest treatment of guava fruits with different concentrations of boric acid and NAA on physical parameters like fruit size, fruit weight and specific gravity have been observed. Ten fruits from each replication per treatment were selected randomly, washed and wiped with muslin cloth. Fruit size was measured by two parameters, i.e., length and breadth by digital Vernier callipers. These fruits were weighed on electronic balance and average fruit weight was calculated. Specific gravity was measured by ration of average weight to volume of fruits and expressed in $g$ $\mathrm{cm}^{-3}$. The recording palatability rating a panel of 5 judges was made. Two fruit each of the chemical treatments were taken and tasted by judges. They were requested to grade it on the basis of general appearance, taste and flavour. Grades were provided on the basis of using following parameters: general appearance (10 marks) and taste and flavours (10 marks). The highest palatability rating of fruit was 20 and the fruits were categorized as excellent (more than 16-20 points), very good (more than 14 to 16), good (more than 12-14 points), fair (more than 10-12) and poor (less than equal to 10). The weight loss of guava fruits was calculated at different storage days in reference to initial weight and expressed as percent loss whereas, decay loss was determined as total rotted decayed fruits in terms of percentage on number basis.

The juice of twenty randomly selected fruits from each replication was extracted and was evaluated for the chemical parameters like TSS, titratable acidity and ascorbic acid. Total soluble solids of juice was recorded at room temperature using digital hand refractometer and was expressed in terms of ${ }^{\circ} \mathrm{Brix}$ (AOAC, 2000). Titratable acidity was determined as citric acid (equivalent weight as $64 \mathrm{~g}$ ) by titrating $10 \mathrm{ml}$ of fruit juice against $\mathrm{N} / 10 \mathrm{NaOH}$, using phenolphthalein as an indicator and was expressed in percentage (1):

Titre valuexnormality of alkalix

Total acidity $(\%)=\frac{\text { equivalent weight of acid }}{\text { Volume of sample taken } \times 1000} \times 100$.....

Ascorbic acid content of fruits juice was determined by 2 , 6-dichlorophenol indophenols visual titration method (AOAC, 1990). The ascorbic acid was computed by using following formula (2):

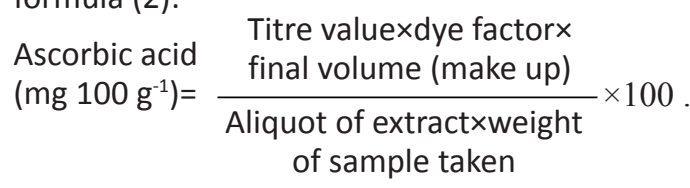

The result were expressed as ascorbic acid $\mathrm{mg} 100 \mathrm{~g}^{-1}$ of the juice. Reducing sugar and total sugar were determined by following the methods of Ranganna (1997).

The data were analysed through completely randomized design (C.R.D.). The overall significance of differences among the treatments was tested, using critical difference (C.D.) at $5 \%$ level of significance.

\section{Results and Discussions}

\subsection{Average fruit weight ( $g$ )}

Application of boric acid and NAA has been reported to be significant for most of the treatments (Table 1). NAA 200ppm and Boric acid 200 ppm were found to be significant as compared to untreated fruit whereas the rest of the treatments were at par with control. The fruits treated with boric acid 100 ppm and 200 ppm, NAA 300 ppm and 400 $\mathrm{ppm}$ and under control were reported to be at par with the mean fruit weight after 3 days while after 12 days the fruits treated with NAA 200 ppm showed highest fruit weight (111.15 g) followed by Boric acid 100 ppm as $110.11 \mathrm{~g}$ which were better than the mean value (109.65 g). The interaction between the treatments and days of storage was reported as non-significant. The relatively higher fruit weight due to application of Boric acid 100 ppm and NAA 200 ppm was due to their ability to reduce fruit respiration rate, thus to reduce the loss of water which is the measure of fruit weight. These results are in conformity with the studies conducted by Blankenship and Dole (2003), El-Sherif et al. (2000); Singh et al. (2004). In the findings of Martinez et al. (2009), the loss of fresh mass during fruit development is a normal response to increased transpiration and respiration, so it is important to minimize these losses (Rawat et al., 2010).

\subsection{Specific gravity $\left(g_{\left(c^{-1}\right.}\right)$}

It is clear from the Table 1 that the specific gravity of the guava fruit decreased continuously with the increase in storage period. However the treated fruit recorded higher value of specific gravity in storage conditions over control. Although specific gravity was reported to be significantly influenced by treatments and days of storage but interaction effect was nonsignificant. The decrease in specific gravity could be due to greater loss of weight in comparison to slow decrease of 
volume and also due to the conversion of starch into sugar. The chemicals like boric acid and NAA reduce the weight loss and respiration, thus were helpful in maintaining higher value of specific gravity. The maximum specific gravity $\left(1.060 \mathrm{~g} \mathrm{cc}^{-1}\right)$ was reported in fruits treated with boric acid $100 \mathrm{ppm}$ followed by boric acid $200 \mathrm{ppm}\left(1.027 \mathrm{~g} \mathrm{cc}^{-1}\right)$ after 12 days of storage. The specific gravity of guava fruits treated with NAA300ppm and boric acid $300 \mathrm{ppm}$ after 12 days of storage was reported to be $0.997 \mathrm{~g} \mathrm{cc}^{-1}$ and $0.983 \mathrm{~g} \mathrm{cc}^{-1}$, respectively was at par with the control (untreated guava fruits).

\subsection{Overall acceptability and palatability rating}

The analysed data on palatability rating of guava fruits treated with chemicals at different days of storage are summarized in Table 1 . The highest mean palatability rating ( 16.33 out of 20 ) was noted in the fruit treated with NAA $300 \mathrm{ppm}$ on day 3 , which was closely followed by (16.00) in boric acid 200 ppm and NAA $200 \mathrm{ppm}$. These fruits were categorized as excellent while other fruits were having very good palatability rating. After 6 days of storage all the fruits were rated with very good palatability while after 9 days of storage the fruits under all treatment have good palatability rating. After 12 days of storage the guava fruits treated with boric acid or NAA had fair rating while the untreated fruits showed poor quality. The effect of chemicals on palatability rating was not significant. However, significant and decreasing trend was reported in taste, texture and appearance in all the storage days. The rapid decrease in score during storage was because of the fruit spoilage. It revealed that fruit treated with different chemicals, boric acid and NAA at different days of storage, get the highest score in fruits treated with boric acid $100 \mathrm{ppm}$ and NAA 300 ppm, which was considered 'excellent' and the lowest score in last day of observation in all treatments due to fruit spoilage. The interaction between treatments and storage days was established non-significant.

\subsection{Total soluble solid (TSS ${ }^{\circ}$ Brix)}

The data pertaining to the TSS of guava fruit as affected by storage duration and postharvest treatment with NAA and boric acid has been specified in Table 2 . The data shows that the TSS increased significantly with different treatments during storage. The Total Soluble Solid ranges from $8.00^{\circ} \mathrm{Brix}$ in fruits treated with NAA $400 \mathrm{ppm}$ at $3^{\text {rd }}$ day of storage to $9.87^{\circ} \mathrm{Brix}$ in fruits treated with Boric acid $100 \mathrm{ppm}$ after 12 days of storage. After 12 days of storage the highest value of TSS was reported in Boric acid $100 \mathrm{ppm}\left(9.87^{\circ} \mathrm{Brix}\right)$ followed by NAA $300 \mathrm{ppm}\left(9.73^{\circ} \mathrm{Brix}\right)$ while the lowest value was in control $\left(9.10^{\circ} \mathrm{Brix}\right)$. The high range of Total Soluble Solid might be due to the efficient translocation of photosynthesis to the fruit by regulation of boric acid and naphthalene acetic acid (NAA). The results are similar to the findings of Rawat et al. (2010). In similar finding, Tarabih and El-Metwally (2014) had reported that boric acid $1.0 \%$ alone or in combination with Jojoba oil (0.1\%) had effectively maintained high TSS of Washington Navel orange fruits stored for 45 days.

\subsection{Weight loss (\%) and fruit decay (\%)}

The observations present in Table 2 that the average weight

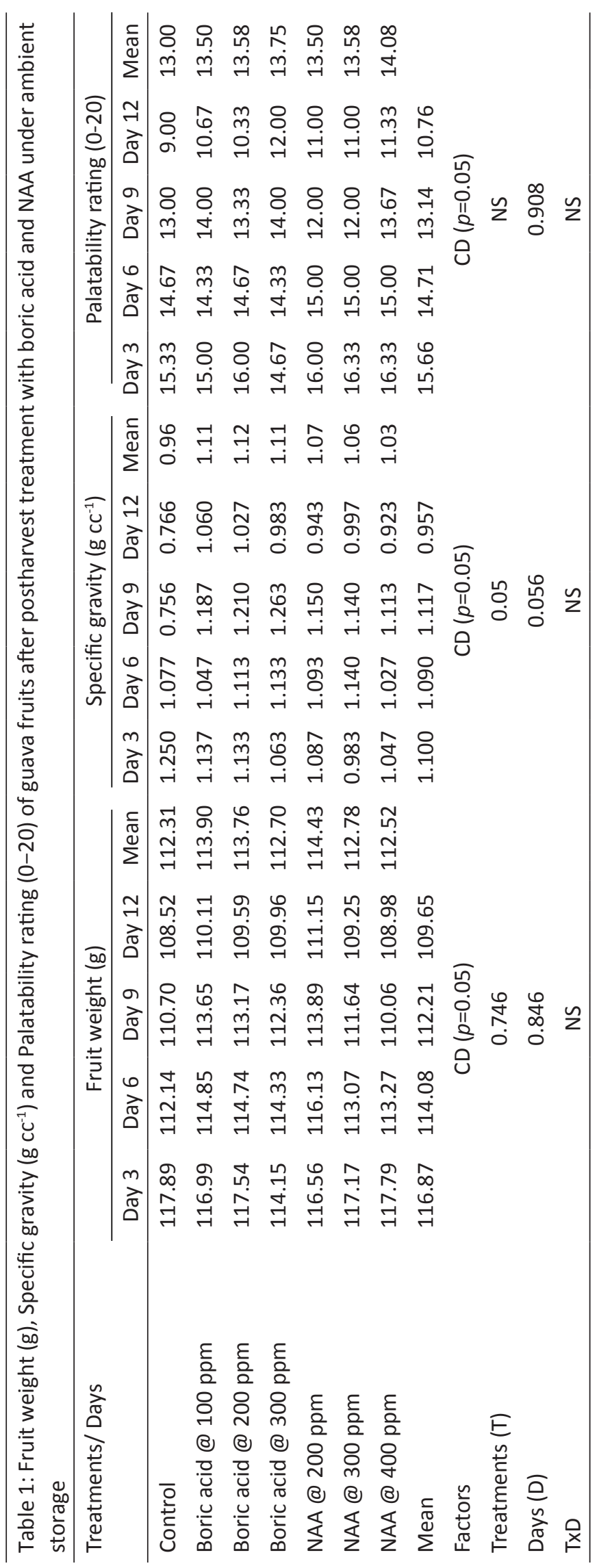




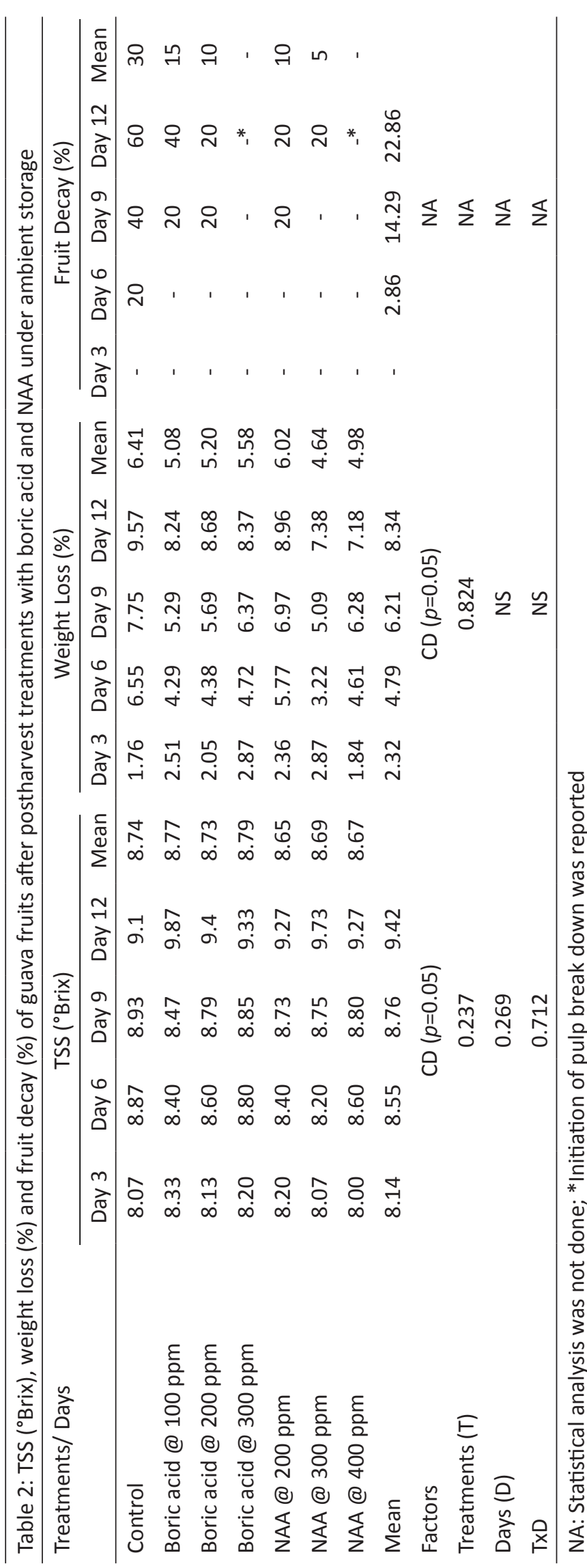

loss of guava fruits under different treatments ranged from $4.64 \%$ in NAA 300 ppm treated guava fruits to $6.41 \%$ in control for ambient storage of guava fruits treated with boric acid and NAA. The weight loss was not significantly affected due to storage days, however treatments have significant effect at various days of storage. At 12 days of storage, the highest weight loss (9.57\%) was reported in control and lowest weight loss (7.18\%) was in NAA 400 ppm treated guava fruits. All treatments have been reported for significant reduction in weight loss over control whereas NAA 400 ppm (7.18\%) and NAA 300 ppm (7.38\%) have been reported to be significant over all other treatments. Guava fruit decay was increased with increasing number of days of storage at ambient temperature. The fruits treated with NAA $400 \mathrm{ppm}$ and boric acid $300 \mathrm{ppm}$ were reported with only minor decay even at 12 days of storage followed by $20 \%$ in NAA 300 ppm, NAA $200 \mathrm{ppm}$ and boric acid $200 \mathrm{ppm}$ while control was reported with maximum (60\%) fruit decay after 12 days of storage. The increasing weight loss and fruit decay in guava during ambient storage was due to water loss and breakdown of pulp at ambient temperature. The increased physiological weight loss in guava during storage has also been reported by Rana et al. (2015). The reduction in physiological weight loss and fruit decay due to treatment with boric acid or NAA might be associated with reduced transpiration and respiration rate in guava tissues and is in conformity with the studies conducted by Blankenship and Dole (2003); Singh et al. (2004); Martinez et al. (2009).

\subsection{Titratable acidity (\%)}

The acidity percentage of guava fruits treated with boric acid and NAA and stored under ambient condition is presented in Table 3. The days of storage shows a significant effect on acid content of fruit in different chemical treatments. Similarly, treatments effect and interaction effect were reported to be significant for TSS content of guava fruits during storage. This increase was greater in fruits treated with different chemicals in comparison to control. The acidity percentage content in different chemicals range from $1.90 \%$ to $0.53 \%$ in ambient temperature. The highest range was observed in NAA $400 \mathrm{ppm}$ $(1.90 \%)$ at $12^{\text {th }}$ days of storage and lowest in $(0.53 \%)$ control at $3^{\text {rd }}$ day of storage, for the ambient temperature. Acidity per cent age of guava fruit might have been augmented due to higher synthesis of nucleic acids, on account of maximum availability of plant metabolism. El-Sherif et al. (2000) have also reported similar results.

\subsection{Ascorbic acid (mg $100 \mathrm{~g}^{-1}$ )}

It is being reflected from Table 3 that the ascorbic acid content

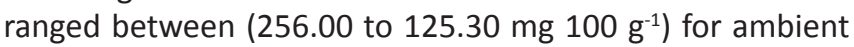
storage of guava fruits treated with boric acid and NAA. The high value was observed in NAA 300 ppm $(256.00 \mathrm{mg} 100$

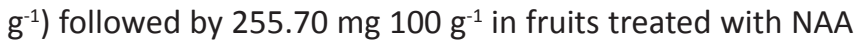
$200 \mathrm{ppm}$ after 3 days of storage. After 12 days of storage the highest value of vitamin-C was reported in fruits treated with NAA 200 ppm (128.00 mg $100 \mathrm{~g}^{-1}$ ) closely followed by boric acid 100 ppm and boric acid 300 ppm and NAA 400 ppm which contain $127.30 \mathrm{mg}$ of vitamin-C $100 \mathrm{~g}^{-1}$ of guava fruit. 
Table 3: Acidity (\%), ascorbic acid (mg $100 \mathrm{~g}^{-1}$ ), reducing sugar (\%) and Total Sugar (\%) of guava fruits after postharvest treatments with boric acid and NAA under ambient storage

\begin{tabular}{|c|c|c|c|c|c|c|c|c|c|c|}
\hline \multirow[t]{2}{*}{ Treatments/ Days } & \multicolumn{5}{|c|}{ Acidity (\%) } & \multicolumn{5}{|c|}{ Ascorbic acid (mg $\left.100 \mathrm{~g}^{-1}\right)$} \\
\hline & Day 3 & Day 6 & Day 9 & Day 12 & Mean & Day 3 & Day 6 & Day 9 & Day 12 & Mean \\
\hline Control & 0.53 & 1.47 & 1.63 & 1.83 & 1.36 & 254.70 & 219.70 & 172.00 & 125.30 & 192.92 \\
\hline Boric acid@100 ppm & 0.53 & 1.33 & 1.77 & 1.80 & 1.36 & 255.00 & 221.00 & 174.30 & 127.30 & 194.42 \\
\hline Boric acid@ 200 ppm & 0.77 & 0.77 & 1.87 & 2.20 & 1.40 & 255.00 & 223.00 & 176.00 & 126.30 & 195.08 \\
\hline Boric acid@ 300 ppm & 1.37 & 1.20 & 1.67 & 1.83 & 1.52 & 254.30 & 222.00 & 177.00 & 127.30 & 195.17 \\
\hline NAA @ 200 ppm & 0.70 & 1.53 & 1.67 & 2.13 & 1.51 & 255.70 & 223.70 & 176.30 & 128.00 & 195.92 \\
\hline NAA @ 300 ppm & 0.80 & 0.80 & 1.73 & 2.23 & 1.39 & 256.00 & 224.00 & 175.00 & 127.00 & 195.50 \\
\hline NAA @ 400 ppm & 1.33 & 1.07 & 1.67 & 1.90 & 1.49 & 255.00 & 223.70 & 176.30 & 127.30 & 195.58 \\
\hline Mean & 0.862 & 1.167 & 1.714 & 1.99 & & 255.10 & 222.43 & 175.29 & 126.95 & \\
\hline Factors & \multicolumn{5}{|c|}{$\mathrm{CD}(p=0.05)$} & \multicolumn{5}{|c|}{$C D(p=0.05)$} \\
\hline Treatments $(T)$ & \multicolumn{5}{|c|}{0.164} & \multicolumn{5}{|c|}{4.645} \\
\hline Days (D) & \multicolumn{5}{|c|}{0.186} & \multicolumn{5}{|c|}{5.267} \\
\hline TxD & \multicolumn{5}{|c|}{0.491} & \multicolumn{5}{|c|}{ NS } \\
\hline
\end{tabular}

Table 3: Continue...

\begin{tabular}{|c|c|c|c|c|c|c|c|c|c|c|}
\hline \multirow[t]{2}{*}{ Treatments/Days } & \multicolumn{5}{|c|}{ Reducing sugar (\%) } & \multicolumn{5}{|c|}{ Total sugar (\%) } \\
\hline & Day 3 & Day 6 & Day 9 & Day 12 & Mean & Day 3 & Day 6 & Day 9 & Day 12 & Mean \\
\hline Control & 5.52 & 5.65 & 5.75 & 5.01 & 5.48 & 11.16 & 11.44 & 11.64 & 10.13 & 11.09 \\
\hline Boric acid@ @100 ppm & 5.41 & 5.49 & 5.62 & 5.08 & 5.40 & 10.94 & 11.12 & 11.38 & 10.33 & 10.94 \\
\hline Boric acid@200 ppm & 5.53 & 5.58 & 5.69 & 5.14 & 5.48 & 11.18 & 11.30 & 11.52 & 10.37 & 11.09 \\
\hline Boric acid @ 300 ppm & 5.46 & 5.52 & 5.57 & 5.21 & 5.44 & 11.04 & 11.18 & 11.28 & 10.49 & 11.00 \\
\hline NAA @ 200 ppm & 5.67 & 5.72 & 5.79 & 5.12 & 5.57 & 11.46 & 11.58 & 11.72 & 10.35 & 11.28 \\
\hline NAA@ @ 300 ppm & 5.56 & 5.77 & 5.97 & 5.15 & 5.61 & 11.24 & 11.68 & 12.08 & 10.51 & 11.38 \\
\hline NAA @ 400 ppm & 5.50 & 5.61 & 5.72 & 5.22 & 5.51 & 11.12 & 11.36 & 11.58 & 10.75 & 11.20 \\
\hline Mean & 5.52 & 5.62 & 5.73 & 5.13 & & 11.16 & 11.38 & 11.60 & 10.56 & \\
\hline Factors & \multicolumn{5}{|c|}{$C D(p=0.05)$} & \multicolumn{5}{|c|}{$C D(p=0.05)$} \\
\hline Treatments $(T)$ & \multicolumn{5}{|c|}{0.142} & \multicolumn{5}{|c|}{0.355} \\
\hline Days (D) & \multicolumn{5}{|c|}{ NS } & \multicolumn{5}{|c|}{1.125} \\
\hline$T x D$ & \multicolumn{5}{|c|}{ NS } & \multicolumn{5}{|c|}{ NS } \\
\hline
\end{tabular}

All the fruits treated with different concentration of NAA and BA were significantly retained vitamin- $\mathrm{C}$ at 12 days of storage

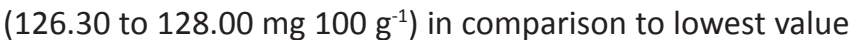

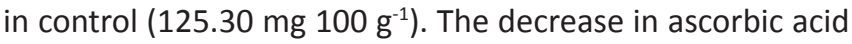
during storage of guava fruits is associated with activity of ascorbic acid oxidase which catalyses oxidation of ascorbic acid into 2-dehydroascorbic acid as proposed by Ohkawa (1989). Similar finding has also been reported by Dhaka et al. (2016) during ambient storage of Kinnow fruit juice.

\subsection{Sugar content (\%)}

The observation recorded on reducing and total sugar content in guava fruits during various days of storage under ambient condition has been presented in Table 3 which shows significant influence of various concentration of boric acid and NAA. The highest reducing sugar (5.97\%) was reported in NAA 300 ppm followed by NAA 200 ppm (5.79\%) and control $(5.75 \%)$ at 9 days of storage whereas lowest reducing sugar (5.01\%) was reported in control at 12 days of storage. Similarly, the highest total sugar (12.08\%) was reported in NAA $300 \mathrm{ppm}$ followed by NAA 200 ppm (11.72\%) and control (11.64\%) at 9 days of storage whereas lowest total sugar $(10.13 \%)$ was reported in control at 12 days of storage. In all treatments reducing and total sugar has shown rise up to 9 days of storage which might be due to breakdown of polysaccharides into monosaccharides and disaccharides but at 12 days of 
storage the sugar content was significantly reduced due to respiratory break down of monosaccharides as confirmed by Jayachandran et al. (2005).

\section{Conclusion}

Guava fruits can be kept under ambient condition for 9 days when treated with Boric acid or NAA. After 9 days, the quality was greatly reduced in terms of palatability rating, ascorbic acid, sugar and acidity content of stored guava fruits. Postharvest treatment of guava fruits with Boric acid @ 200-300 ppm, NAA @ 200 ppm-400 ppm for 1-2 minutes had retained fair palatability value (more than 11) till 9 days of ambient storage while ascorbic acid was significant (upto $50 \%)$ till 12 days of storage.

\section{Acknowledge}

The authors acknowledge the Lovely Professional University, Phagwara, Punjab for providing the required facilities for successful completion of research work.

\section{References}

AOAC, 2000. Official methods of analysis, $17^{\text {th }}$ edn. Association of Official Analytical Chemists, Washington DC.

Bal, E., Celik, S., 2010. The effects of postharvest treatments of salicylic acid and potassium permanganateon the storage of kiwifruit. Bulgarian Journal of Agricultural Science 16(5), 576-584.

Blankenship, S.M., Dole, J.M., 2003. 1-Methylcyclopropene: a review. Postharvest biology and technology 28(1), 1-25.

Chemists, A.O.A., Cunniff, P., 1990. Official methods of analysis Association of Official Analytical Chemists, Washington, D. C.

Deepthi, V.P., Sekhar, R.C., 2015. Post-harvest physiological and biochemical changes in guava (cv. LUCKNOW-49) fruits harvested at two stages of maturity during low temperature storage.International Journal of Processing and Post-harvest Technology 6(2), 128-143.

Deepthi, V.P., Sekhar, R.C., Srihari, D., Sankar, A.S., 2016. Guava fruit quality and storability as influenced harvest by maturity and postharvest application ofcalcium salts. Plant Archives 16(1), 174-182.

Dhaka, A., Sharma, M., Singh, S.K., 2016. Use of Additives to Reduce Browning, Microbial Load and Quality Loss of Kinnow Juice under Ambient Storage. Indian Journal of Science and Technology 9(14), DOI: 10.17485/ijst/2016/ v9i14/80907, April 2016.

El-Anany, A.M., Hassan, G.F.A., 2013. Impact of activated carbon from date pits, potassium permanganate and their combination on extending the postharvest quality of three maturity stages of guava during cold storage. International Journal of Postharvest Technology and Innovation 3(4), 403-425.

El-Sherif, A.A., Saeed, W.T., Nouman, V.F., 2000. Effect of foliar application of potassium and zinc on behaviour of Montakhab El-Kanater guava trees. Bulletin of Faculty of Agriculture, University of Cairo, 51(1), 73-84.
Jayachandran, K.S., Srihari, D., Reddy, Y.N., 2005. Changes in post-harvest quality of guava fruits affected by preharvest application of growth regulators. Agricultural Science Digest 25(3), 210-212.

Kaur, S., Jawandha, S.K., Singh, H., 2016. Effect of chemicals and modified atmosphere packaging on selected physico-chemical characteristics of Baramasi lemon fruits at ambient conditions. Journal of Environmental Biology 37(3), 349.

Madan, H.S., Ullasa, B.A., 1993. Postharvest losses in fruits. Advances in horticulture 4, 1795-1810.

Mahajan, B.V.C., Ghuman, B.S., Bons, H.K., 2011. Effect of post-harvest treatment of Calcium Chloride and Gibbrellic Acid on storagebehaviour and quality of guava fruits. Journal of Horticultural Science \& Ornamental Plants 3(1), 38-42.

Martinez, A.T., Ruiz-Duenas, F.J., Martinez, M.J., del Rio, J.C., Gutierrez, A., 2009. Enzymatic delignification of plant cell wall: from nature to mill. Current Opinion in Biotechnology 20(3), 348-357.

Ohkawa, J., Okada, N., Shinmyo, A., Takano, M., 1989. Primary structure of cucumber (Cucumis sativus) ascorbate oxidase deduced from cDNA sequence: homology with blue copper proteins and tissue-specific expression. Proceedings of the National Academy of Sciences 86(4), 1239-1243.

Pila, N., Gol, N.B., Rao, T.R., 2010. Effect of post-harvest treatments on physicochemical characteristics and shelf life of tomato (Lycopersicon esculentum Mill.) fruits during storage. American-Eurasian Journal Agricultural and Environmental Sciences 9(5), 470-479.

Rana, S., Siddiqui, S., Goyal, A., 2015. Extension of the shelf life of guava by individual packaging with cling and shrink films. Journal of food science and technology 52(12), 8148-8155.

Ranganna, S., 1997. In: Manual on Analysis of Fruit and Vegetable Products. Tata McGraw Hill Publishing Co., New Delhi.

Rawat, V.R.Y.T.J., Tomar, Y.K., Rawat, J.M.S., 2010. Influence of foliar application of micronutrients on the fruit quality of guava cv. Lucknow-49. Journal of Hill Agriculture I(I), 63, 66.

Singh, R., Chaturvedi, O.P., Singh, R., 2004. Effect of pre harvest spray of zinc, boron and calcium on the physicochemical quality of guava fruits (Psidium guajava L.). In: Internal Seminar on Recent Trend in Hi-Tech Horticulture and Post-harvest Technology, 4-6.

Singh, S.K., Sharma, M., Singh, P.K., 2016. Combined approach of intercropping and INM to improve availability of soil and leaf nutrients in fruit trees. Journal of Chemical and Pharmaceutical Sciences 9(2), 823-829.

Tarabih, M.E., El- Metwally, M.A., 2014. Effect of Jojoba oil and Boric acid as postharvest treatment on shelf life of Washington Navel orange fruits. International Journal of Agricultural Research 9(1), 1-16. 